\title{
Pubertal Food Intake, Body Length, Weight, and Composition in the Well Fed Female Rat
}

\author{
RICHARD WILEN ${ }^{(39)}$ AND FREDERICK NAFTOLIN \\ Department of Obstetrics and Gynecology, McGill University, Royal Victoria Hospital, Women's Pavilion, \\ Montreal, Quebec, Canada
}

\begin{abstract}
Summary
Pubertal age, food intake, body length, weight, and composition were determined by direct measurements in 29 well fed female rats studied from birth to first estrus. The average birth and weaning weights of the 12 early maturing rats were $6.99 \pm$ $0.13 \mathrm{~g}$ and $50.13 \pm 1.16 \mathrm{~g}$, respectively, and did not differ significantly from those of the 11 late maturers $(6.97 \pm 0.16 \mathrm{~g}$ and $49.72 \pm 1.42 \mathrm{~g}$, respectively). Mean values for all pubertal measurements are included in Table 1. At puberty, the late maturing animals were heavier, longer, and had attained a greater quantity of total body water than the early maturers. Although both groups ate the same total amounts of food, late maturing rats at vaginal opening and at first estrus consumed relatively less food per $100 \mathrm{~g}$ body weight than did early maturers. Estrus was simultaneous with vaginal opening in 10 $(83 \%)$ of early and $4(36 \%)$ of the late maturing rats. Despite the similarity in the proportions of total body water, fat, and
\end{abstract}

protein in early and late maturers, a regression analysis, shown in Figure 1 , indicates a significant decrease in the proportion of body water $(P<0.001)$, and a significant increase in the proportion of body fat $(P<0.05)$ with increasing age at first estrus. The percentage of body protein does not change with increasing age at first estrus (regression coefficient $=\mathbf{0 . 1 3}$ ).

\section{Speculation}

Our findings in female rats are consistent with those in monkeys and domestic animals which show pubertal age to be positively correlated with body weight. These observations are at variance with results reported for girls who show an unchanging average body weight at all ages of puberty. The differences in metabolic and somatic development observed in pubertal rats suggest that the attainment of a "critical" body weight, level of fat, and food intake may not be the principal factors initiating puberty. 
Studies on female rodents $(24,35)$, domestic animals $(6,21)$, and humans (7) have shown that at sexual maturation, average body weights are the same for well- and undernourished subjects. The undernourished, however, attain maturity at a greater age. Studies on well-nourished early and late maturing girls show that average weight at menarche is the same, but that the late maturers are taller (11). Food or caloric intake per 100 grams of body weight is the same at puberty for rats that are well- or undernourished (24) or fed a high or low fat diet ad libitum (9). Nonetheless, as age at first estrus increases within groups of rats, body weight increases while food intake per 100 grams of
body weight decreases (9).

In rats (24) and in humans (11) the attainment of a certain body weight and associated metabolic rate has been hypothesised to be a signal for the initiation of puberty. More recently, studies based on estimated total body water in pubertal girls have suggested that, in addition to acquiring a "critical" body weight and metabolic rate at puberty, individuals must reach a "critical"
level of fatness (10). Unfortunately, studies with direct measurements of body composition are not available. Because of the absence of studies which report the relationships of pubertal age with food intake and body length, weight and the relationships of pubertal age with food intake and body length, weight and these variables in well-fed pubertal female laboratory rats.

\section{MATERIALS AND METHODS}

Rats (Sprague-Oawley, Charles River Strain), obtained at a time at which they were pregnant for no more than two weeks, were individually caged in our
laboratory. Temperature $\left(21^{\circ} \mathrm{C}\right)$ and 1 ight $(14 \mathrm{hr}$. daily) were controlled. At birth, pups were separated from their mothers and male pups discarded. Litters of ten female pups were randomly placed with mothers that had just given birth and had had their pups removed. Mothers were fed Purina Laboratory Chow and watered ad libitum, and individually caged with their pups. Pups were weaned at 21 days of age and placed in individual cages. Twenty-nine pups were fed an fat by Frisch et al. (9) contains percentages of fat and protein similar to those found in Purina Laboratory Chow. Each pup was weighed (to the neares $0.1 \mathrm{~g}$.) every other day from birth to first estrus and at vaginal opening. Food intake was determined at 24 hour intervals by weighing the food containers (to the nearest $0.1 \mathrm{~g}$.) from which the weaned pups ate. From time of weaning rats were observed daily for vaginal opening. Thereafter, vaginal smears were take daily to determine first estrus (first appearance of completely cornified epi-
thelial cells). Pubertal food intake was taken to be the average daily anount thelial cells). Pubertal food intake was taken to be the average dally anlount
of food consumed during the 72 hours prior to first estrus or vaginal opening. of food consumed during the 72 hours prior to first estrus or vaginal opening.
At first estrus, rats were sacrificed by ether anesthesia and weighed; noserump length was recorded with a standard sliding compass. Rats were then immediately sealed into individual plastic bags and frozen for future body composition analysis. The frozen carcasses were chopped into small pieces and placed in tared aluminum dishes. They were dried at $95^{\circ} \mathrm{C}$. to constant weight. The weight loss was taken to equal total body water. The dried carcasses were then crostraction for a minimum of four hours using petroleum ether on $5 \mathrm{~g}$. portions was used to determine percentage of fat. Two
gram portions of the powdered fat-free carcasses were heated with $50 \mathrm{ml}$. of $50 \%$ sulfurtc actd for $3-4$ days at alproximately $100^{\circ} \mathrm{C}$. The hydrolysate was quanti volume. The total nitrogen content of this solution was determined by the micro-Kjeldahl method and was corrected to protein content by multiplying by factor of 6.25 (17). Rats were specified as early or late maturers by using the median age at first estrus ( 38.0 days) as the dividing point. Six animals attained first estrus at the median age of 38 days and thus were not included in either group. The statistical significance of mean values and regression slopes were determined by a student $t$-test $(30)$.

1. Optimal diet: casein 20\%, starch $70.3^{\%}$, fat (hydrogenated vegetable oilSpry. Lever Brothers, New York) $5 \%$, vitamin mix $0.5 \%$ (16), salt mix $4 \%$

RESULTS

of the 23 experimental animals not having first estrus on the median (the $38 \mathrm{th})$ day for the total population, 12 rats in which first estrus occurred be fore 38 days of age were specified as early maturers and 11 rats whose age at first estrus exceeded 38 days were designated as late maturers. The average
$( \pm$ S.E.) birth and weaning weights of early maturing rats were $6.99 \pm 0.13 \mathrm{~g}$. and $50.13 \pm 1.16 \mathrm{~g}$. . respectively, and did not differ significantly from those of late maturers $(6.97 \pm 0.16 \mathrm{~g}$. and $49.72 \pm 1.42 \mathrm{~g}$. , respectively). Estrus was simultaneous with vaginal opening in $10\left(83^{*}\right)$ of the early and $4\left(36^{\sim}\right)$ of the late maturing rats. Late maturing rats were significantly heavier and longer than early naturers (Table 1). The use of the mean day of first estrus diving point resulted in an uneven distribution of early and late maturers. Despite this, the calculations for food intake and somatic variables at first estrus and at vaginal opening using the mean age at first estrus ( 39.6 essentially the same findings.

Although late maturing rats have a significantly greater amount of total body water at first estrus, their average percentage of total body fat, pro-
tein and water are the same as in the early maturers (Table 1). Nonetheless a regression analysis using all twenty-nine rats shows that the percentage of total body water, which is the inverse of body fatness $(17)$, decreases $(P<0.001)$
while the percentage of total body fat increases $(P<0.05)$. with increasing while the percentage of total body fat increases ( $P<0.05$ ). With increasing increasing age at estrus (regression coefficient $=0.13$ ).

Early and late maturing rats at vaginal opening and at first estrus consume the same amount of food; however, food inta

\section{DISCUSSION}

The finding that early and late maturing laboratory rats attain a different body weight and percentage of fat at first estrus is apparently discordant with the hypothesis that a "critical" body weight representing a critical level of fatness and metabolic rate may trigger the initiation of puberty
(10). Our observation that body weight at puberty increases with age in the rat is at variance with reports on girls showing early and late maturing subjects attaining the same average body weight at menarche $(11,37)$. The disparity of these observations may be explained by variations in the adolescent weight spurt prior to menarche (32). Furthermore, different racial groups have different weights at menarche (20). In the American girls reported, group hetero-
geneity may mask a more racially defined, positively correlated, age and weight geneity may mask a more $r$
relationship at menarche.

Differences in pubertal age-weight distributions may occur between humans and other mammals. A recent study of the well-fed pubertal rhesus monkey $(36)$ shows that the rhesus at menarche, like the ewe ( 7 ) and the heifer (1) at first
estrus has a pubertal age-weight distribution similar to the rat at first es-
trus.
Deceleration of skeletal growth is highly correlated with the timing of sexual maturation in mammals (32). That well-fed, late maturing rats ar greater capacity for additional bone growth in late (Table 1) suggests a both well- and undernourished late maturing girls are taller than their earlier maturing counterparts $(8,11)$.

The proportion of total body fat increases from birth to adulthood in female rodents $(5,14)$ and humans $(4,10)$. In humans, estrogen formation from androgen precursors has been demonstrated in vitro in adipose tissue $(13,29)$. Moreover, levels of estrogen excretion and metabolism in adult women may vary directly with increasing body weight (3) and percentage of estimated fat (10). Estrogen formation by rodent body fat has, however, yet to be demonstrated. Furthermore, the attainment of early puberty in light lean female rats and
other species (36) suggests that a high level of body fat associated with the attainment of a "critical" body weight may not be the principal factors initiating sexual maturation. To this extent, the lower percentage of simultaneous vaginal opening and estrus found in heavy, fat, late maturing rats may reflect characteristically diminished pituitary function associated with low levels of food intake and metabolic rate (Table 1) (24). Chronically underfed late maturing rats that are gonadotropin deficient display a prolonged interval
between onset of pubertal events (24). In the sexually maturing female rat esbetween onset of pubertal events (24). In the sexually maturing female rat e
trogen begins acting to suppress food intake and rate of weight gain (33) as trogen begins acting to suppress food intake and rate of weight gain (33) as
its ability to induce pubertal events increases (31). In the late maturing well-fed rat, a low but rising sensitivity to increasing levels of circulating gonadotropin and estrogen would offer a partial explanation for the increased gonadotropin and estrogen would offer a partial explanation for the increased growth observed at vaginal opening and at first estrus. The local production
of estrogen from androgen precursors by the limbic and hypothalamic tissues controlling gonadotropin secretion has already been raised as having a possible role in the development of sexual maturation (28).

Kennedy (23) regarded food intake or its correlate, metabolic rate, as a trigger which might change hypothalamic control of gonadotropins and thereby initiate puberty (24). The hypothes is was formulated from observations on well- and underfed rats that attained puberty at differing ages even though they were eating the same amount per unit of body weight (24). In contrast, the presently studied late maturing rats, heavier and proportionately fatter than their early maturing controls, consume less food per unft of body weight (Table 1). This is consistent with observations on increasingly lower metaheat-producing body mass increases at a greater rate than their heat-radiating surface area (2). Moreover, it is suggested that some compensating effect of greater proportional body fat thought important in regulating energy balance by the hypothalamus $(18,19,22)$ may play a role in lowering food intake/100 grams of body weight in the fatter, late maturing animals (fig. 1). Although early and late maturing girls weigh the same, early maturer
be fatter (10) and may consume less calories daily (25).

In female rats (14) and humans (4) the percentage of total body prote in portion of body prote in (an approximate measure of lean body mass or body cell and late maturing rats (Table 1) or giris (22) at puberty.

Well-fed pubertal female rats with varying body weight, percent fat, or food intake may be generating a similar but yet to be defined metabolic signa the onset of sexual maturation.

\section{CONCLUSION}

Birth, weaning and pubertal body weights were studied in 29 rats. Food intake, body length, and body composition at sexual maturation (first estrus) were measured. Contrary to an existing bel ief based on evidence gathered from observations on rats and humans (references in the Introduction to the paper). that in a homogeneous group, sexual maturation is attained at an approximately trus the later maturing rats are heavier, fatter and consume a lesser amount of food per unit of body weight than the early maturers. We present evidence that late maturers at first estrus.

\section{REFERENCES}

1. Arije, G.E. and Wiltbank, J.N.: Age and weight at puberty in Hereford

2. Brody S. Bioenergetics and Growth: 1971.

with Special References to the Animals (Reinhold Publishing Corporation.

New York, 1945)

thyroid function on $107,1965$.

4. Cheek, D.B.: Body composition, hormones, nutrition and adolescent growth in: M.M. Grumbach, G.D. Grave and F.E. Mayer: Control of the Onset of Puberty, pp. 424-447 (John Wiley and Sons, Inc., New York, 1974).

5. Cheek, D.B. and Holt, A.B.: Growth and body composition of the mouse. Am. J. Physiol., 205: 913, 1963.

6. Crichton, J.A., Aitken, J.N. and Boyne, A.W.: The effect of plane of nutrition during rearing on growth, production, reproduction and healt of dairy cattle. I. Growth to 24 months. Anim. Prod., 1: 145, 1959.

- Oýnundsson, O.R. and Lees, J.L.: A note of factors affe

8. Clun Forest female lambs. Anim. Prod. 15: 311 , 1972 . under-nourished girls at differing ages and evidence for historical consistency. Pediatrics, 50: 445, 1972.

9. Frisch, R.E.. Hegsted, D.M. and Yoshinaga, K.: Body weight and food intake at early estrus of rats on a high fat diet. Proc. Nat. Acad. Sci. 72: 4172,1975 .

10. Frisch, R.E. and McArthur, J.: Menstrual cycles: fatness as a determinan of minimal weight for height necessary for their maintenance or onset. Science, 185: 949, 1974

11. Frisch, R.E. and Revelle, R,: Height and weight at menarche and a hypothesis of $\mathrm{cr}$ it
i69: $397,1970$.

12. Frisch, R.E., Revelle, R. and Cook, S.: Components of the critical weight at menarche and at initiation of the adolescent spurt: estimated total water, lean body mass and fat. Human Biol., 45: 469, 1973.

13. Gallegos, A.J. and Cannales, E.S.: In vitro estrogenic production by human mamary gland. Endocrine Society:
New York. N.Y. Abstract 99 , p. 80, 1969.

14. Hataf, S.: Changes in the body composition of the entire body of the

albino rat during the life span. Am. J. Anat., 21: 23, 1917

Hayes, K.C., Rabin, A.R. and Berson, E.L.: An ultrastructural study of nutritionaily
$505,1975$. 
16. Hegsted, D.M., Gallagher, A. and Hanford, H.: Inositol requirement of the gerbil. J. Nutr., 104: 588, 1974.

17. Hegsted, D.M., Gallagher, A. and Hanford, H.: Reducing diets in rats. Am. J. C1in. Nutr. 28: $837,1975$.

18. Hervey, G.R.: Regulation of energy balance. Nature. 222: 629, 1969.

19. Hervey, G.R.: Physiological mechanisms for the regulation of energy

20. Johnston, F.E., Roche, A.F., Schell, L.M. and Wettenhall, N.B.: Critical weight at menarche: critique of a hypothesis. Am. J. Dis. Child., 129: $19,1975$.

21. Joubert, D.M.: Puberty in female farm animals. Anim. Breeding Abstracts 31: 295,1963

22. Kennedy, G.C.: The role of depot fat in the hypothalamic control of food intake in the rat. Proc. R. Soc. B., 140: 578, 1953.

23. Kennedy, G.C.: Interactions between feeding behavior and homones during growth. Ann. N.Y. Acad. Sci., 157: 1049, 1969

24. Kennedy, G.C. and Mitra, J.: Body weight and food intake as initiating factors for puberty in the rat. J. Physiol 166: 408, 1963.

25. Mitchell, H.S., Reed, R.B., Valadian, I. and Hoff, M.: The adolescent growth spurt and nutrient intake. Proc. 7 th Int. Cong. Nutrition, 4:

26. Monteiro, L.S. and Falconer, D.S.: Compensatory growth and sexual

27. maturity in mice. Anim. Prod. 8: 179.1966.

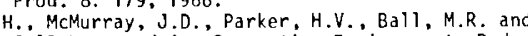
and its Supporting Environment: Body Composi

28. Naftolin, F., Ryan, K.J., Davies, I.J., Reddy, V.V., Flores, F., Petro, Kuhn, M., White, R.J., Takaoka, Y. and Wol in, L.: The formation of estrogens by central neuroendocrine tissues. Recent Prog. Horm. Res. 31: 295,1975 .

29. Shindler, A.E., Ebert, A. and Friedrich, E.: Conversion of androstenedione to estrone by human fat tissue. J. Clin. Endocrinol. Metab., 35 627,1972 .
30. Snedecor, G.W. and Cochran, W.G.: Statistical Methods, Ed. 6 (Iowa State University Press, Ames, Lowa, 1967).

31. Sodersten, P.: Receptive behaviour in developing female rats. Horm. Behav.. 6: 307, 1975.

32. Tanner, J.M.: Growth at Adolescence, Ed. 2 (Blackwell Scientific Publications, Oxford, 1962)

33. Wade, G.N. and Zucker, I.: Development of hormonal control over food intake and body weight in female rats. J. Comp. Physiol. Psychol. 70: 213,1970

34. Waite, B. and Robert, L.J.: Studies in the food requirement of adolescent girls: I. The energy intake of well-nourished girls 10 to 16 years of age. J. Am. Dietet

35. Widdows on, E.M., Mavor, H.O. and McCance, R.A.: Effect of undernutrition and rehabilitation on the development of the reproductive organs: rats. J. Endocrin

36. Wilen, R. and Naftolin, F.: Age, weight and weight gain in the individual pubertal female rhesus monkey (Macaca mulatta). Eiol. Reprod., 15: 356,

37. Zacharias, L., Rand, W.M. and Wurtman, R.J.: A prospective study of sexual development and growth in American girls: the statistics of

This study wat. Gynecol. Survey, 31: 325, 1976.

study was supported by funds from the Department of Anthropology, Harvard University, Obstetrics and Gynecology Research Funds, Royal

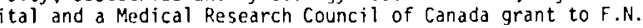
We are grateful to Dr. Mark Hegsted for providing us with the laboratory the diet, to Mr. John wyse for assistance with the statistical analysis, and to Mrs. Elaine Waddington for her help in preparing the manuscript.

39. Requests for reprints should be addressed to: Dr. Richard Wilen, Women's Pavilion, Royal Victoria Hospital, 687 Pine Avenue West, Montreal, Quebec, Canada. H3A IAl

40. Received for publication September 27,1976

41. Accepted for publication December 14, 1976.

TABLE 1. Mean ( \pm SEM) age, weight, and food intake at vaginal opening and at first estrus. Mean nose-rump length, total body water, and percent body water, fat and protein at first estrus.

\begin{tabular}{|c|c|c|c|c|c|}
\hline & \multirow{2}{*}{$\frac{\text { Early Maturers }}{N=12}$} & \multirow{2}{*}{$\frac{\text { Late Maturers }}{N=11}$} & \multirow{2}{*}{$\begin{array}{l}\text { All rats } \\
\text { combined } \\
N=29\end{array}$} & \multicolumn{2}{|c|}{$\begin{array}{l}\text { Early and lat } \\
\text { Differences }\end{array}$} \\
\hline & & & & $t$ & $P$ \\
\hline \multicolumn{6}{|l|}{ At Vaginal Opening } \\
\hline $\begin{array}{l}\text { Age (days) } \\
\text { Body Weight, BWt (g) } \\
\text { Food Intake, FI (g/day) } \\
\text { FI/100 g } 8 W t / \text { dav }(\mathrm{g})\end{array}$ & $\begin{aligned} 34.2 & \pm 0.47 \\
122.7 & \pm 3.30 \\
14.3 & \pm 0.58 \\
11.7 & \pm 0.23\end{aligned}$ & $\begin{aligned} 42.4 & \pm 1.60 \\
150.0 & \pm 7.70 \\
16.0 & \pm 0.87 \\
10.7 & \pm 0.27\end{aligned}$ & $\begin{aligned} 37.9 & \pm 0.94 \\
135.3 & \pm 3.99 \\
15.1 & \pm 0.43 \\
11.1 & \pm 0.17\end{aligned}$ & $\begin{array}{l}5.2 \\
3.4 \\
1.7 \\
2.8\end{array}$ & $\begin{array}{c}<0.001 \\
<0.005 \\
n .5 \\
<0.01\end{array}$ \\
\hline \multicolumn{6}{|l|}{ At First Estrus } \\
\hline $\begin{array}{l}\text { Age (days) } \\
\text { BWt ( } \mathrm{g}) \\
\text { Nose-Rump Length }(\mathrm{cm}) \\
\text { rotal Body Water. TBW }(\mathrm{g}\rangle \\
\text { TWB/BWt. Percent. } \\
\text { Percent Fat } \\
\text { Percent Protein } \\
\text { FI/day }(\mathrm{g}) \\
\text { FI/100 } \mathrm{g} \text { BWt/day }(\mathrm{g})\end{array}$ & $\begin{aligned} 34.6 & \pm 0.51 \\
124.8 & \pm 3.36 \\
15.2 & \pm 0.14 \\
83.9 & \pm 1.78 \\
67.7 & \pm 0.60 \\
9.1 & \pm 0.35 \\
17.9 & \pm 0.43 \\
14.4 & \pm 0.57 \\
11.5 & \pm 0.24\end{aligned}$ & $\begin{aligned} 45.9 & \pm 2.01 \\
162.4 & \pm 9.60 \\
16.5 & \pm 0.30 \\
107.1 & \pm 4.96 \\
66.0 & \pm 0.90 \\
10.6 & \pm 0.88 \\
17.5 & \pm 0.56 \\
14.9 & \pm 0.89 \\
9.3 & \pm 0.62\end{aligned}$ & $\begin{aligned} 39.6 & \pm 1.23 \\
143.3 & \pm 5.79 \\
15.8 & \pm 0.17 \\
94.6 & \pm 2.80 \\
66.9 & \pm 0.48 \\
9.9 & \pm 0.47 \\
17.6 & \pm 0.29 \\
14.7 & \pm 0.41 \\
10.5 & \pm 0.31\end{aligned}$ & $\begin{array}{l}5.7 \\
3.4 \\
4.0 \\
4.6 \\
1.6 \\
1.6 \\
0.5 \\
0.5 \\
3.4\end{array}$ & $\begin{aligned} &< 0.001 \\
&<0.005 \\
&<0.001 \\
&<0.001 \\
& \text { n.s. } \\
& \text { n.s. } \\
& \text { n.s. } \\
& \text { n.s. } \\
&<0.005\end{aligned}$ \\
\hline
\end{tabular}

n.s. = not significant.
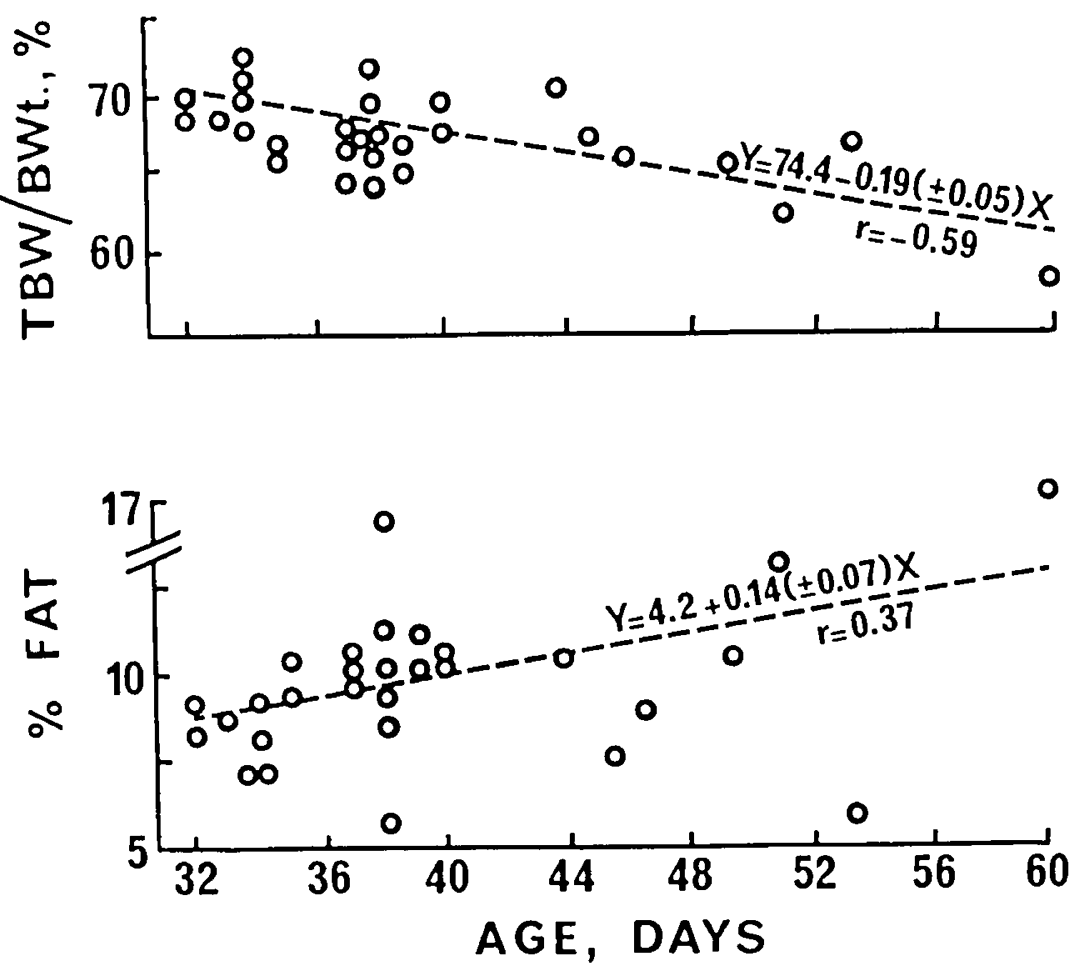

Fig. 1. The percentage of total body water and fat at first estrus in the well-fed rat. 